\title{
Earthworms - the most effective agriculture proponent
}

\author{
Askarkhadzhaeva Aziza Nodirovna ${ }^{1}$, Askarhajaeva Karima Usmanjanovna ${ }^{2}$ \\ ${ }^{1}$ Doctoral candidate at the National University of Uzbekistan, Department of Human and \\ Animal Physiology, Uzbekistan \\ ${ }^{2}$ Associate professor of the Department of Informatics and Management, KamoliddinBehzod \\ National Institute of Arts and Design, Uzbekistan
}

Email: askarxadjayeva_a@umail.uz

\begin{abstract}
This article discusses the importance of earthworms in agriculture. Its origin, development and practical significance are explained.
\end{abstract}

Keywords: rain worms, processing technologies, macropores, agricultural technology.

\section{INTRODUCTION}

Earthworms or earthworms (lat. Lumbricina) - a suborder of small-bristle worms from the order Haplotaxida. They live on all continents except Antarctica, however, only a few species initially had a wide range: the distribution of a number of representatives occurred due to human introduction. The most famous European earthworms belong to the family Lumbricidae. The body length of representatives of different species varies from $2 \mathrm{~cm}$ (genus Dichogaster) to $3 \mathrm{~m}$ (Megascolidesaustralis). The number of segments is also variable: from 80 to 300 . When moving, earthworms rely on short bristles located on each segment except the front. The number of bristles varies from 8 to several tens (in some tropical species).

\section{THEORETICAL BACKGROUND}

The circulatory system in worms is closed, well developed, blood has a red color. The earthworm has two main blood vessels: the dorsal, through which the blood moves from the back of the body to the front, and the abdominal, in which the blood moves from the front of the body to the back. These two vessels are connected by annular vessels in each segment, some of them, called "hearts", can contract, providing the movement of blood. Vessels branch into small capillaries. Breathing is carried out through the skin rich in sensitive cells, which is covered with protective mucus. Mucus is saturated with a huge amount of enzymes that are antiseptics. The nervous system of earthworms consists of a poorly developed brain (two nerve nodes) and an abdominal chain. They have a developed ability to regenerate.

\section{MAIN PART}

Earthworms are hermaphrodites, each sexually mature individual has a female and male reproductive system (synchronous hermaphroditism). They reproduce sexually using cross fertilization. Reproduction occurs through the girdle, inside which the eggs are fertilized and develop. The belt occupies several front segments of the worm, standing out relative to the rest of the body. The exit from the belt of small worms occurs after 2-4 weeks in the form of a cocoon, and after 3-4 months they grow to the size of adult individuals.

Breeding earthworms (vermiculture) allows you to process various types of organic waste into high-quality environmentally friendly fertilizer - vermicompost. In addition, due to the fecundity of worms, their biomass can be increased for use as feed additives to the diet of farm animals and poultry. For breeding worms, compost is prepared from various organic wastes: manure, chicken droppings, straw, sawdust, fallen leaves, weeds, branches of trees and bushes, wastes from the processing industry, vegetable stores, etc. After environmental conditions in the compost lead to optimal, the worms are 
settled in compost. After 2-3 months, breeding worms are sampled from the resulting biohumus. For the first time, the practice of using certain epigeneous species of earthworms to obtain compost was proposed in the USA; George Sheffield Oliver and Thomas Barrett became pioneers in this field [5]. The latter conducted research on his Earthmaster Farms from 1937 to 1950 and played an important role in convincing colleagues of the value and potential importance of earthworms in agricultural technology

Digging moves with earthworms leads to aeration and drainage of the soil. In addition, nutrients are released from plant debris after passing through their intestines. Farmers can contribute to the development of worms by maintaining a high amount of nutrients in the land and using less destructive tillage technology. In normal soil on arable farms, there can be from 100,000 to 1,000,000 worms, with a total weight of 100 to $1000 \mathrm{~kg}$, per hectare. They play a very important role for the soil in carrying out their work. Through their activity, earthworms increase drainage and aeration of the soil, making channels for water and air leading to the subsoil. In addition to their effects on drainage and aeration, earthworms also affect other physical properties of the soil.

The number of pores increases and the density of dry matter of the soil decreases when the worms break through their passages through the soil. Soil cultivation by worms greatly increases the number of macropores (diameter> $0.5 \mathrm{~mm}$ ) and creates a network of channels and voids in the soil. This network can be 4000-5000 km long per hectare and tunnels can go 2-3 $\mathrm{m}$ in depth. Tunnels act as highways for roots in the soil. For several years, on each hectare, earthworms will raise tens of tons of land to the surface in the form of excrement.

Soil biology improves naturally from the moment that the activity of earthworms stimulates the activity of microorganisms, spreading fungi and bacteria widely in the soil profile. Ultimately, this affects the chemical composition of the soil, as the effectiveness of almost all nutrients increases after they pass through the intestines of the worms. For example, in the excrement of worms, the nitrate concentration is 8 times higher than in the rest of the soil. Worm excrement acts as an adhesive between particles of soil, which improves aggregation stability and soil structure. Earthworms are sensitive to many components of modern agriculture, such as pesticides and soil compaction. Tillage is an important factor as he worries worms, disrupting their system of moves. This is especially true in September and October, when reproduction occurs. Agrotechnical methods can be classified according to the harm caused to the worms in the following order: direct sowing <tooth cultivation <stubble cultivation <subsurface plowing <plowing with a turnover of the reservoir. The impact of plowing on worms is a matter of debate. One study showed that as a result of plowing, $10 \%$ of the total mass of worms are on the surface. Birds eat the third part, the remaining two third find a way to avoid death and return to the ground.

\section{CONCLUSION}

To support the worms, it is important to feed them regularly. The best way to do this is to include clover in the crop rotation. Nevertheless, any technique that increases the amount of organic matter in the soil is a positive factor for the number of earthworms. Green manure and green manure are also great food for them.In just a few years of active use of a crop rotation containing cereal grasses and clover instead of winter wheat, the number of worms in these crops can be increased by $100 \%$. Therefore, worms are a good indicator of soil fertility. Where they thrive, culture will flourish.

\section{REFERENCES}

1. Malevich I. I. Earthworms - article from the Great Soviet Encyclopedia Zoology of invertebrates. T. 1: from protozoa to mollusks and arthropods. Ed. W. Westheide and R. Rieger. M .: T-number of scientific publications of KMK, 2008, $512 \mathrm{p}$.

2. Earthworms: Renewers of Agroecosystems (SA Fall, 1990) Archived July 13, 2007.Edwards C. A. Introduction, history, and potential of vermicomposting technology // Vermiculture Technology. Earthworms, Organic Wastes, and Environmental Management. - Boca Raton, London, New York: CRC Press, 2011. - 1-11 p.

3. .Reading the works of Avicenna // G. N. Uzhegov "Recipes of ancient medicine", - M .: Rusich, 1997, 
4. Gates, G. E. On Regenerative Capacity of Earthworms of the Family Lumbricidae (Eng.) // The American Midland Naturalist: journal. - 1953. - 1 January (vol. 50, no. 2). - P. 414-419.

5. MamajonovaG.K. Bioethics-A component of culture: development tendencies and basic features //International Journal on Integrated Education. - 2019. - T. 2. - №. 4. - C. 116-118.

6. MamajonovaG.K.The role of bioethics in fostering the family's spiritual foundations //International Journal of Advanced Science and Technology. - 2019. - T. 28. - №.12. - C. 397 401.

7. Mamajonova G. K. BIOETHICS IS APPLIED ETHICS //Теорияипрактикасовременнойнауки. - 2018. - №. 1. - С. 29-31. 